\title{
Additional Evidence of Arboreality of the Greater Windward Sleink, Copeoglossum aurae (Reptilia: Squamata: Mabuyidae), on Carriacou (Grenada Grenadines)
}

\author{
Billie C. Harrison, ${ }^{1}$ Richard A. Sajdak, ${ }^{2}$ Robert W. Henderson, ${ }^{1}$ and Robert Powell ${ }^{3}$ \\ ${ }^{1}$ Milwaukee Public Museum, Milwaukee, Wisconsin 53233, USA \\ ${ }^{2}$ Pittsford, New York 14534, USA \\ ${ }^{3}$ Department of Biology, Avila University, Kansas City, Missouri 64145, USA
}

$\mathrm{R}$ elatively little is known about habitat use by the Greater Windward Skink (Copeoglossum aurae), which occurs on the St. Vincent and Grenada Banks in the Lesser Antilles, on Trinidad and Tobago, and possibly on the Península de Paria (Sucre, Venezuela). Hedges and Conn (2012) noted that earlier information pertaining to this species (e.g., Daudin and de Silva 2007, 2011; Henderson and Powell 2009; Malhotra and Thorpe 1999; Murphy 1997) was likely compromised by confusion between the sympatric Greater and Lesser Windward Skinks (Marisora aurulae), which were considered conspecific, usually under the name Mabuya mabouya, until Hedges and Conn (2012) reviewed the skinks of Caribbean islands.

Murphy et al. (2013) noted that these skinks are frequently above the ground in trees, bushes, or on anthropo- genic structures, suggesting that they are arboreal. They listed a number of observations of individuals on Trinidad and Tobago that were above the ground and provided additional evidence of arboreality in the form of photographs of an individual being eaten by a Brown Vinesnake (Oxybelis aeneus) and two skinks in copula on the trunk of a tree. However, additional observations of these skinks on the ground in leaf litter and under rocks and logs in open forested habitats indicated that they are not entirely arboreal.

In the most recent guide to the amphibians and reptiles of Trinidad \& Tobago, Murphy et al. (2018) stated that these skinks are found in forested and disturbed areas, where they use a variety of habitats but often are on vertical surfaces. They went on to indicate that the species "is mostly arboreal; but may sleep on the ground."

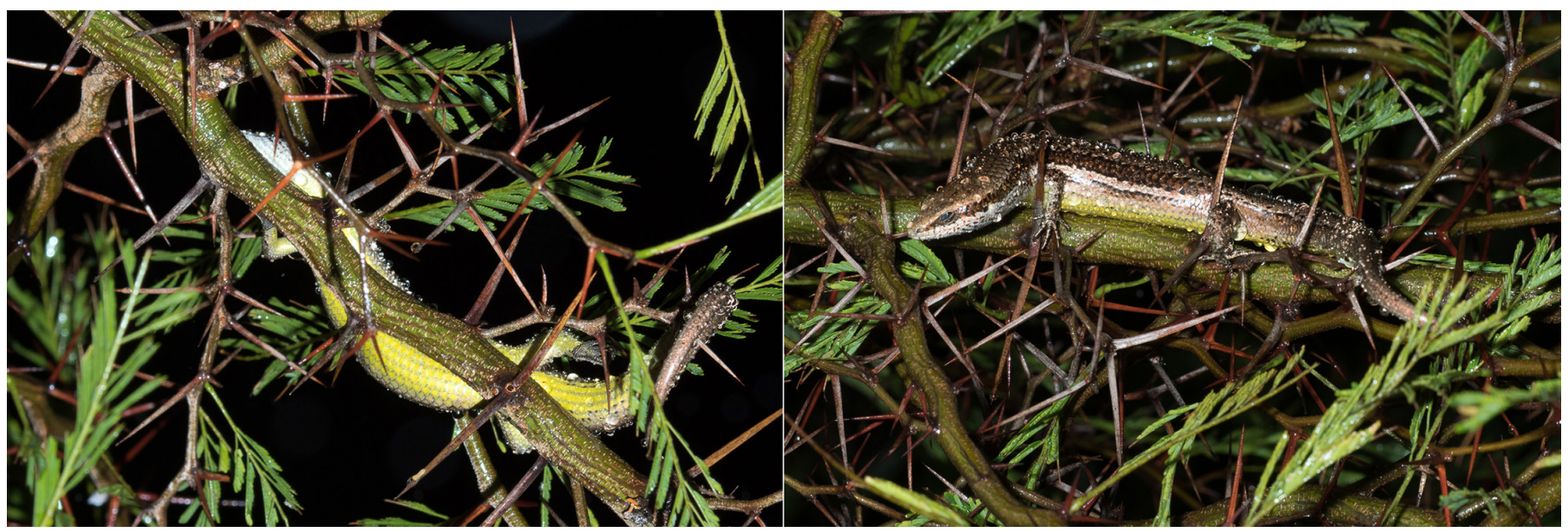

Fig. 1. An adult Greater Windward Skink (Copeoglossum aurae) sleeping on a thorny Acacia branch on Carriacou (Grenada Grenadines). Photographs by R.A. Sajdak. 


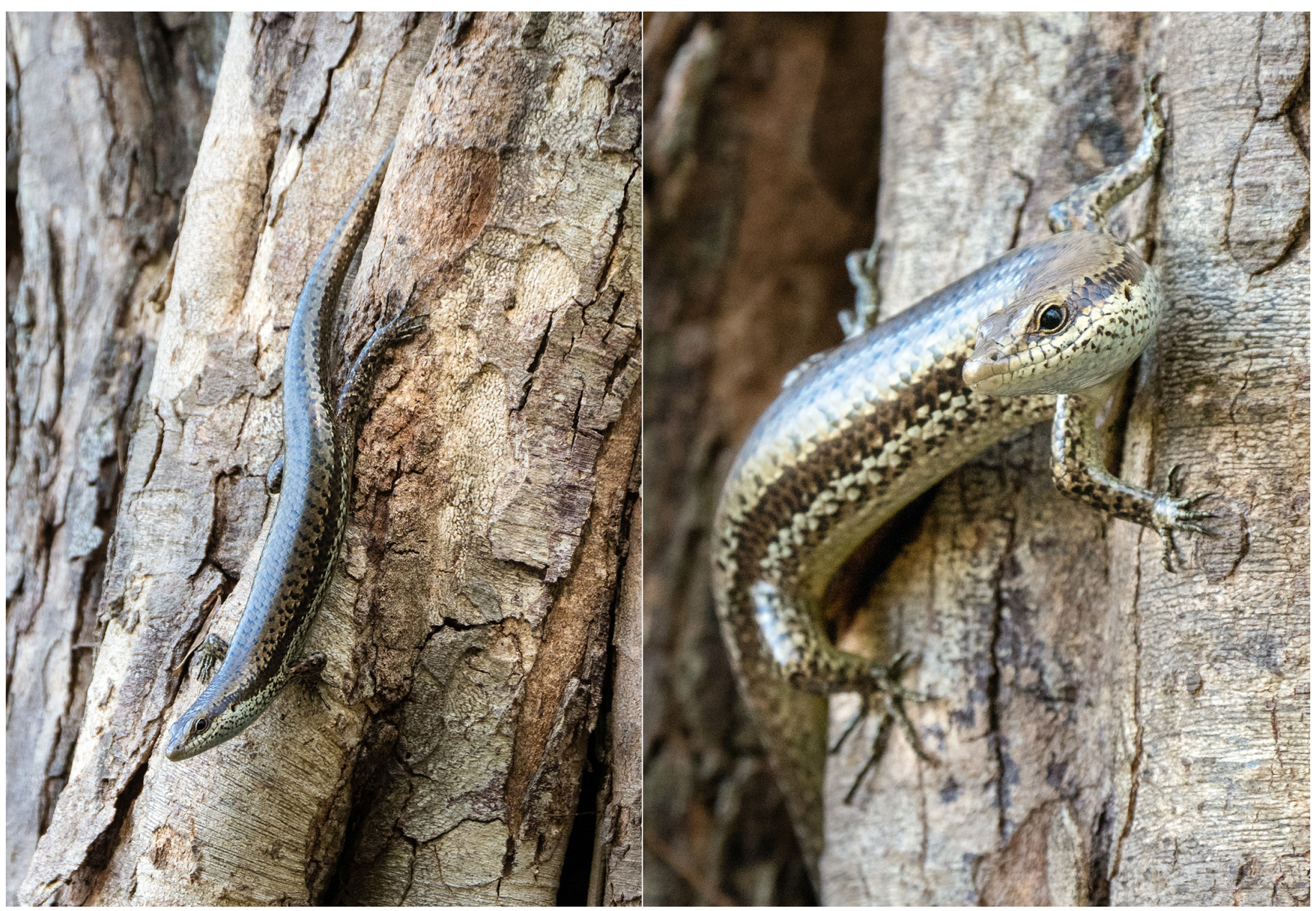

Fig. 2. An adult Greater Windward Skink (Copeoglossum aurae) on the trunk of a tree with numerous cavities on Carriacou (Grenada Grenadines). Photographs by R.A. Sajdak.

Henderson and Powell (2018) lacked data for habitat associations on St. Vincent but noted the presence of the species in agricultural land and deciduous forests/thorny scrub on the Grenada Bank. Citing observations that might have included Marisora aurulae, which appears to be less arboreal, they stated that "although they will ascend into bushes and trees, skinks are largely ground-dwelling." However, confirmed sightings of $C$. aurae in the Grenadines included an individual in the rafters of an abandoned shed on Union and another $2 \mathrm{~m}$ above the ground in a hole in a rotting tree on Mustique.

At about $2000 \mathrm{~h}$ during a rainy evening in dry scrub on Carriacou (Grenada Grenadines), we encountered an adult Greater Windward Skink sleeping on a thorny branch of an Acacia (Fig. 1) about $2.1 \mathrm{~m}$ above the ground. The next morning at about $1100 \mathrm{~h}$ in deciduous forest at another site on Carriacou, we found another individual about $0.9 \mathrm{~m}$ above the ground on a tree trunk with numerous cavities (Fig. 2), into one of which it eventually retreated. These observations provide additional evidence of arboreality in $C$. aurae, including the first record of an individual sleeping on an exposed branch much like many species of anoles (e.g., Henderson and Powell 2009).

\section{Literature Cited}

Daudin, J. and M. de Silva. 2007. An annotated checklist of the amphibians and terrestrial reptiles of the Grenadines with notes on their local natural history and conservation. Applied Herpetology 4: 163-175.

Daudin, J., and M. de Silva. 2011. An annotated checklist of the amphibians and terrestrial reptiles of the Grenadines with notes on their local natural history and conservation, pp. 259-271. In: A. Hailey, B.S. Wilson, and J.A. Horrocks (eds.), Conservation of Caribbean Island Herpetofaunas. Volume 2: Regional Accounts of the West Indies. Brill, Leiden, The Netherlands.

Hedges, S.B. and C.E. Conn. 2012. A new skink fauna from Caribbean islands (Squamata: Mabuyidae: Mabuyinae). Zootaxa 3288: 1-244.

Henderson, R.W. and R. Powell. 2009. Natural History of West Indian Reptiles and Amphibians. University Press of Florida, Gainesville.

Henderson, R.W. and R. Powell. 2018. Amphibians and Reptiles of the St. Vincent and Grenada Banks, West Indies. Edition Chimaira, Frankfurt am Main, Germany.

Malhotra, A. and R.S. Thorpe. 1999. Reptiles \& Amphibians of the Eastern Caribbean. Macmillan Education, London.

Murphy, J.C. 1997. Amphibians and Reptiles of Trinidad and Tobago. Krieger Publishing Company, Malabar, Florida.

Murphy, J.C., S. Charles, M. Rutherford, T. Anton, G. Hast, B. Reynolds, J. Traub, and G. White. 2013. The Greater Windward Skink, Copeoglossum aurae (Reptilia: Squamata: Mabuyidae), a semi-arboreal lizard of the eastern Caribbean. Living World, Journal of the Trinidad and Tobago Field Naturalists' Club 2013: 57-58.

Murphy, J.C., J.R. Downie, J.M. Smith, S.M. Livingstone, R.S. Mohammed, R.M. Lehtinen, M. Eyre, J.-A.N. Dewlal, N. Noriega, G.S. Casper, T. Anton, M.G. Rutherford, A.L. Braswell, and M.J. Jowers. 2018. A Field Guide to the Amphibians \& Reptiles of Trinidad \& Tobago. Trinidad \& Tobago Field Naturalists' Club, Port of Spain, Republic of Trinidad and Tobago. 